\title{
Penentuan Distribusi Suhu pada Permukaan Geometri Tak Tentu Menggunakan Metode Random Walk
}

\author{
Balduyanus Yosep Godjaa), Andi Ihwana) ${ }^{\text {a }}$, Apriansyah ${ }^{\text {b) }}$ \\ aJurusan Fisika Fakultas Matematika dan Ilmu pengetahuan Alam, bJurusan Ilmu Kelautan Fakultas \\ Matematika dan Ilmu pengetahuan Alam Universitas Tanjungpura \\ Jalan Prof. Dr. Hadari Nawawi, Pontianak, Indonesia \\ *Email : andihwan@physics.untan.ac.id
}

\begin{abstract}
Abstrak
Telah dilakukan penentuan distribusi suhu dalam keadaan tunak pada sebuah plat bergeometri tak tentu menggunakan metode Random Walk yang dilengkapi fungsi green. Setiap sisi plat dikondisikan bervariasi terhadap suhu dalam rentang $10^{\circ} \mathrm{C}$ sampai $100^{\circ} \mathrm{C}$ dengan 4 (empat) konfigurasi berkeadaan steady. Persamaan Laplace yang mendeskripsikan permasalahan ini dihampiri dengan mensimulasikan sejumlah walker pada setiap titik domain permasalahan untuk kemudian secara acak disebar menuju ke setiap sisi plat. Hasil yang diperoleh untuk setiap kondisi plat menunjukkan kesalahan relatif terhadap solusi numerik metode iterasi jacobi yang telah menghampiri solusi analitik, secara rata-rata adalah $0,85 \%$. Nilai kesalahan tersebut diperoleh dengan menggunakan 5000 walker. Penelitian ini juga mendapatkan bahwa akurasi hampiran ditentukan oleh banyaknya walker yang digunakan. Secara umum, semakin banyak jumlah walker yang digunakan maka akurasi hampiran akan semakin baik.
\end{abstract}

Kata Kunci : Persamaan Laplace, Distribusi Suhu, Random Walk, Walker, Geometri Tak Tentu

\section{Latar Belakang}

Fenomena fisis terkait distribusi suhu keadaan tunak pada sebuah permukaan maupun ruangan direpresentasikan secara matematis menggunakan persamaan diferensial parsial [1]. Untuk beberapa fenomena sederhana, persamaan diferensial dapat dicari solusinya secara analitik baik menggunakan teknik separasi variabel maupun teknik perhitungan matematis lainnya. Namun untuk kasus yang lebih kompleks, penyelesaian solusi analitik sangat sulit untuk dilakukan karena kerumitan penerapan syarat batas maupun faktor simetri permasalahan.

Untuk memecahkan permasalahan

tersebut, dilakukan pencarian solusi alternatif menggunakan metode numerik, yaitu menghampiri persamaan diferensial secara langsung menggunakan deret Taylor dan teknik kalkulus variasi [2] maupun memanfaatkan variabel acak [3] untuk mendekati fenomena yang ditinjau. Untuk pilihan pertama, kerumitan masih terkandung di dalam proses pencarian. Sedangkan pada pilihan kedua kerumitan masih akan muncul pada penerapan syarat batas dan jenis geometri permasalahan yang ditinjau. Khusus untuk pendekatan menggunakan variabel acak, tingkat kerumitan sedikit tereduksi karena metode ini menirukan proses fisis yang terjadi secara acak atau random hanya dengan memperhitungkan probabilitasnya. Pemilihan metode ini bagi sebagian kasus distribusi didasarkan pada kesederhanaan operasi matematisnya.

Pada penelitian ini dilakukan pencarian distribusi suhu pada sebuah permukaan geometri tak tentu menggunakan metode random walk. Geometri permasalahan awal yang ditinjau adalah benda bersimetri bujur sangkar yang diberi perlakuan suhu tertentu untuk kemudian dicari distribusi suhunya pada keadaan steady. Persamaan diferensial parsial yang merepresentasikan keadaan ini adalah persamaan Laplace [1]. Faktor geometri yang menjadi kerumitan untuk metode numerik yang lain direduksi kerumitannya dengan menghitung fungsi Green pada fungsi ditribusi suhu yang ditinjau. Fungsi Green tersebut akan diperoleh dengan memanfaatkan sejumlah walker yang disebar ke seluruh domain permasalahan yang kemudian akan dihitung frekuensi transitnya pada batas domain.

\section{Metodologi}

\section{$2.1 \quad$ Metode Random Walk}

Dalam penelitian ini, penentuan distribusi suhu dihitung menggunakan metode Random walk dimana solusi persamaannya adalah [4]:

$$
T(x, y)=\frac{1}{n} \sum_{x b, y b} G(x, y, x b, y b) T(x b, y b)
$$




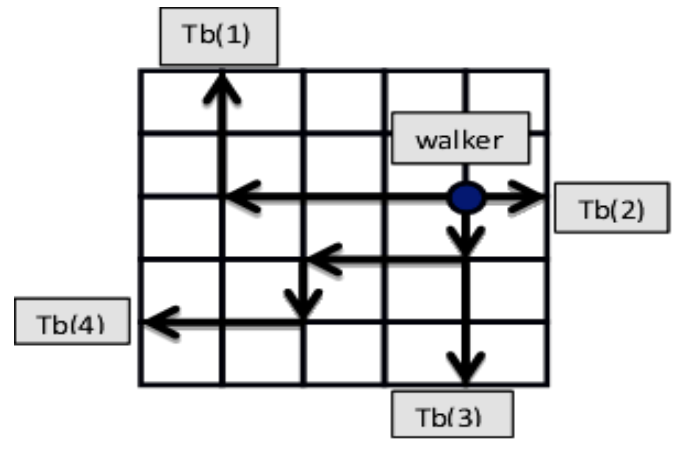

Gambar 1. Metode random walk

Algoritma metode random walk (Gambar 1) untuk menghitung solusi persamaan Laplace dituliskan sebagai berikut:

a Dimulai dari titik $(x, y)$ dimana nilai temperatur yang diinginkan. Langkah diambil dalam arah acak.

b Selanjutnya walker dijalankan hingga mencapai permukaan. $T_{b}$ dicatat sebagai temperatur pada batas (i)

c Langkah 1 dan 2 diulangi setiap waktu dan temperatur yang didapat dijumlahkan pada permukaan.

d Nilai dari temperatur pada titik $(x, y)$ dihasilkan oleh persamaan (1) dimana $n$ jumlah walker dari random walk.

\subsection{Deskripsi Model}

Deskripsi model yang digunakan adalah plat segi empat dengan ukuran $(10 \times 10) \mathrm{cm}$ dengan perlakuan syarat batas seperti Gambar 2 .

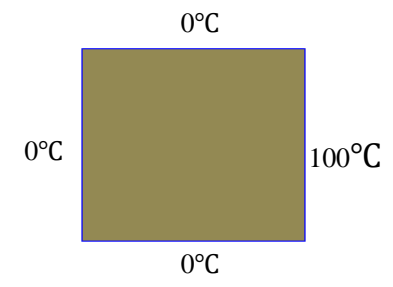

Gambar 2. Plat Segi Empat

Persamaan yang digunakan untuk masalah model adalah persamaan konduksi panas dua dimensi keadaan tunak atau dikenal sebagai persamaan Laplace berikut:

$$
\frac{\partial^{2} T}{\partial x^{2}}+\frac{\partial^{2} T}{\partial y^{2}}=0
$$

\subsection{Model Analitik dan Model Numerik}

Penyelesaian analitik persamaan dengan nilai awal dan syarat batas sesuai dengan deskripsi model yang selanjutnya disebut sebagai
Model Analitik dirumuskan di persamaan (3) berikut:

$$
\mathrm{T}=\frac{400}{\pi} \sum_{n \text { ganjil }} \frac{1}{n \sinh n \pi} \sinh \frac{n \pi}{10}(x) \sin \frac{n \pi}{10} y
$$

Diskritisasi numerik (Model Numerik/ MN) dalam penyelesaian persamaan (2) menggunakan metode iterasi jacobi [1]:

$$
T_{i, j}^{k+1}=\frac{1}{2\left(1+\beta^{2}\right)}\left[T_{i+1, j}^{k}+T_{i-1, j}^{k}+\beta^{2}\left(T_{i, j+1}^{k}+T_{i, j-1}^{k}\right)\right]
$$

Metode iterasi jacobi digunakan sebagai validasi terhadap solusi analitik. Kondisi tersebut diilustrasikan pada Gambar 2.

\subsection{Skenario Model}

Skenario model pada penelitian adalah plat bergeometri tak tentu seperti pada Gambar 3.

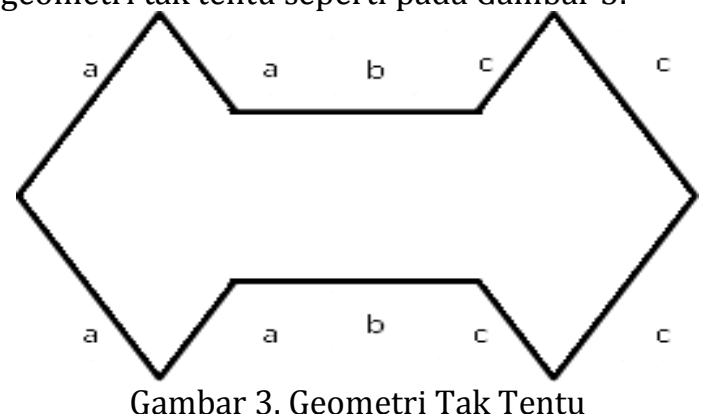

Berikut adalah kondisi-kondisi yang akan disimulasi pada penelitian ini

Tabel 1. Tabel Kondisi Suhu Geometri Tak Tentu

\begin{tabular}{c|c|c|c}
\hline Kondisi & $\mathrm{a}\left({ }^{\circ} \mathrm{C}\right)$ & $\mathrm{b}\left({ }^{\circ} \mathrm{C}\right)$ & $\mathrm{c}\left({ }^{\circ} \mathrm{C}\right)$ \\
\hline I & 100 & 75 & 10 \\
II & 100 & 10 & 75 \\
\hline
\end{tabular}

\section{$2.5 \quad$ Selisih Relatif RMS}

Tingkat kesalahan pada penelitian ini menggunakan persamaan (5) yaitu Root Mean Square Error (RMSE). RMSE adalah parameter statistik yang menginformasikan pengguna model tentang ukuran aktual error yang dihasilkan oleh model [5].

$$
\operatorname{RMSE}(\%)=\sqrt{\frac{(T(\mathrm{i}, \mathrm{j})-\mathrm{T}(\mathrm{x}, \mathrm{y}) / \mathrm{T}(\mathrm{i}, \mathrm{j}))^{2}}{\mathrm{~N}}} \times 100 \%
$$

Keterangan:

$\mathrm{T}(\mathrm{i}, \mathrm{j})=$ Nilai suhu metode iterasi jacobi

$\mathrm{T}(\mathrm{x}, \mathrm{y}) \quad=$ Nilai suhu metode random walk

$\mathrm{N}=$ jumlah data 


\section{Hasil dan Simulasi}

\subsection{Validasi Solusi Metode Random walk terhadap Solusi Metode Iterasi jacobi}

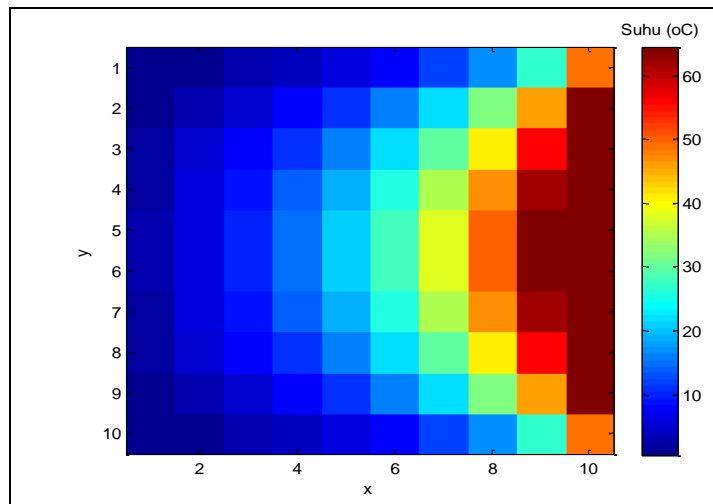

(a)

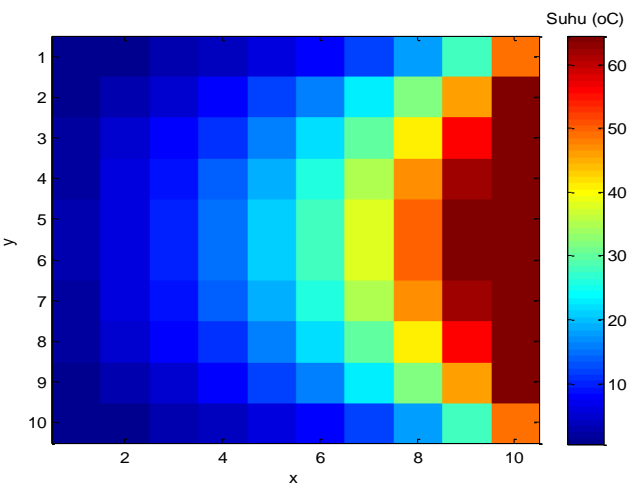

(b)

Gambar 4. Hasil Plot Solusi Metode Iterasi Jacobi (a) dan Solusi Analitik (b) Plat Segi Empat

Untuk solusi metode iterasi jacobi dan solusi analitik pada kasus plat segi empat memiliki pola distribusi suhu yang relatif sama seperti pada
Gambar 4 dan memilki RMS eror (0,8 \%). Sehingga solusi numerik Metode Iterasi Jacobi dapat digunakan untuk validasi Metode Random Walk.

\subsection{Distribusi Suhu Permukaan Geometri Tak Tentu menggunakan Metode Random Walk pada Kondisi I}

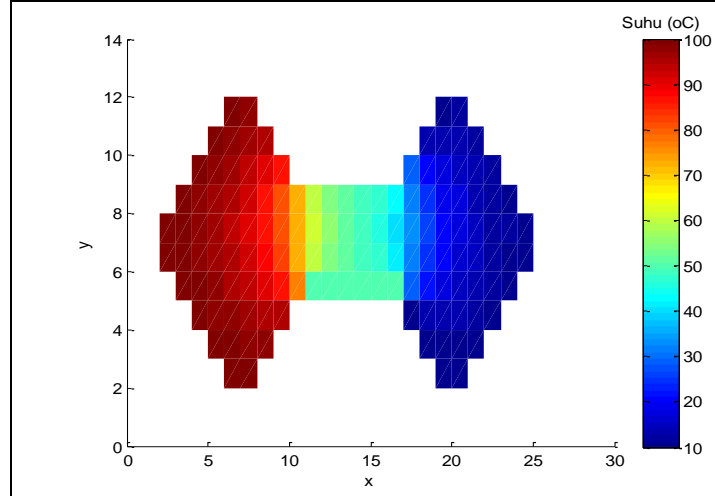

(a)

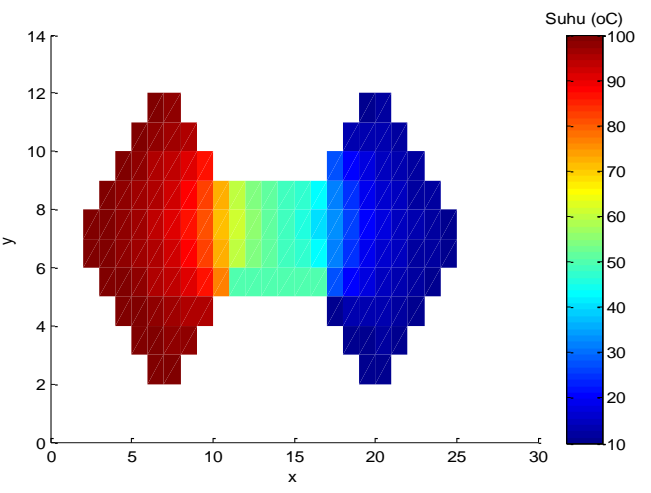

(b)

Gambar 5. Hasil Plot Solusi Metode Random Walk (a) walker 5000 (b) Metode Iterasi Jacobi Kondisi(I)

Pada Gambar 5, memperlihatkan bahwa pola distribusi suhu dari kedua metode relatif sama. Distribusi suhu cenderung menyebar tidak merata pada geometri tak tentu. Pada sisi kiri gambar diberi kondisi kalor yang lebih besar dibanding sisi tengah dan sisi kanan. Gradasi temperatur terlihat landai di sisi kanan plat. Hal ini disebabkan daerah sisi kanan plat merupakan sumber kalor bagi sisi kiri dan sisi tengah plat. Sedangkan sisi kiri plat dijaga dengan batas domain $10{ }^{\circ} \mathrm{C}$ tidak memberikan kontribusi suhu yang signifikan terhadap aliran kalor. Untuk melihat proses perpindahan suhu disimulasikan grafik penampang melintang domain kondisi, seperti pada Gambar (6) 


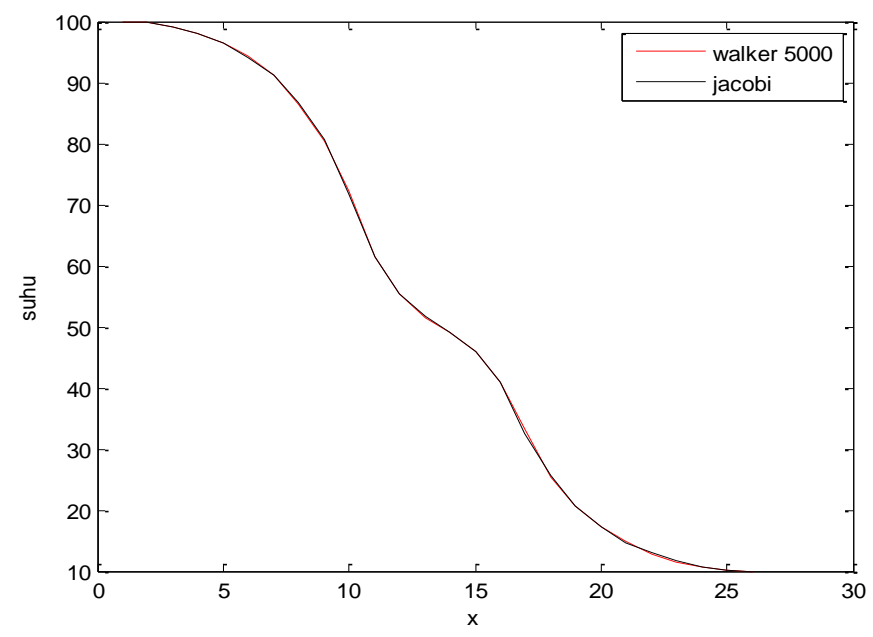

Gambar 6. Grafik Penampang Melintang Plat Geometri Tak Tentu Kondisi (I)

Dari grafik yang ditunjukkan Gambar 6 menjelaskan bahwa aliran kalor yang terjadi adalah dari suhu tertinggi ke suhu rendah dengan 3 variasi batas domain. Hal ini diakibatkan adanya perbedaan suhu yang menunjukan adanya proses perpindahan kalor.

Persamaan (1) fungsi green G menyatakan banyaknya frekuensi walker yang berhenti pada syarat batas. Ditinjau dari titik pada domain suhu yang akan ditentukan secara geometri walker akan cenderung berhenti pada syarat batas domain terdekat dari sumber panas. Pada syarat batas $100{ }^{\circ} \mathrm{C}$ titik domain suhu yang dekat dengan syarat batas ini memiliki jumlah walker lebih banyak dari titik domain suhu yang terdekat dengan kedua syarat batas lainnya. Sama halnya dengan syarat batas $50{ }^{\circ} \mathrm{C}$ dan $10{ }^{\circ} \mathrm{C}$. Jumlah keseluruhan walker sama dengan walker yang disimulasikan yaitu 5000 .

\subsection{Distribusi Suhu Permukaan Geometri Tak Tentu menggunakan Metode Random Walk pada Kondisi II}

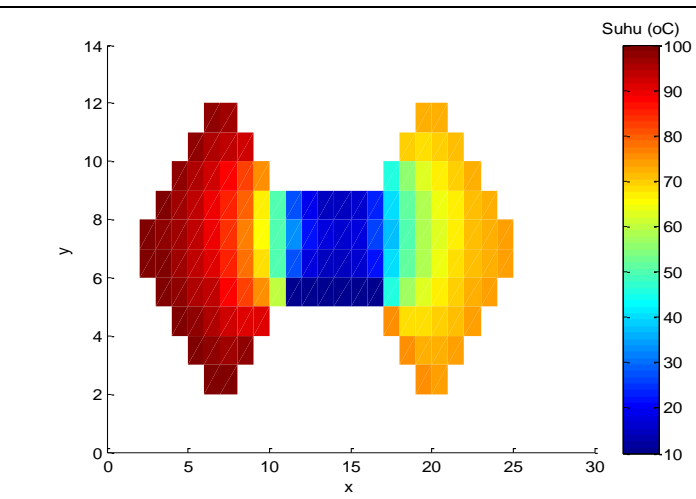

(a)

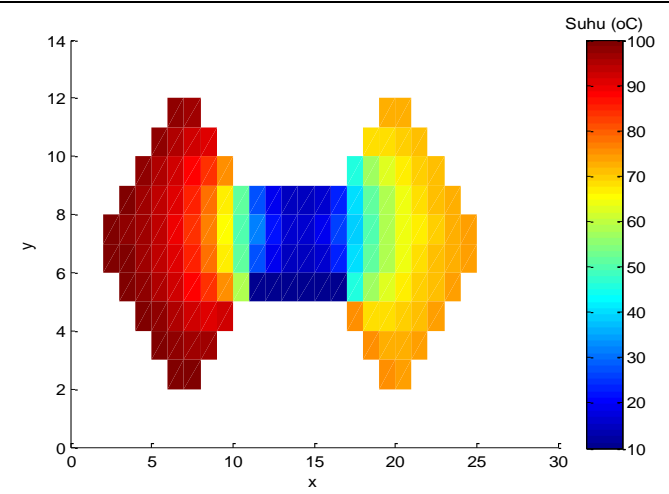

(b)

Gambar 7. Hasil Plot Solusi Metode RandomWalk (a) walker 5000 (b) Metode Iterasi Jacobi Kondisi (II)

Dapat dilihat dari Gambar 7, bahwa kedua metode memilki pola sebaran suhu yang relatif sama. Bagian tengah plat geometri tak tentu merupakan domain dengan kondisi suhu terkecil. Hal ini mengakibatkan daerah ini merupakan daerah transfer kalor dari kedua sisi. Gradasi suhu yang terjadi terlihat curam di tengah dan sedikit melandai ke arah domain batas ujung plat.

Grafik penampang melintang domain kondisi dapat menunjukkan pola aliran suhu: 


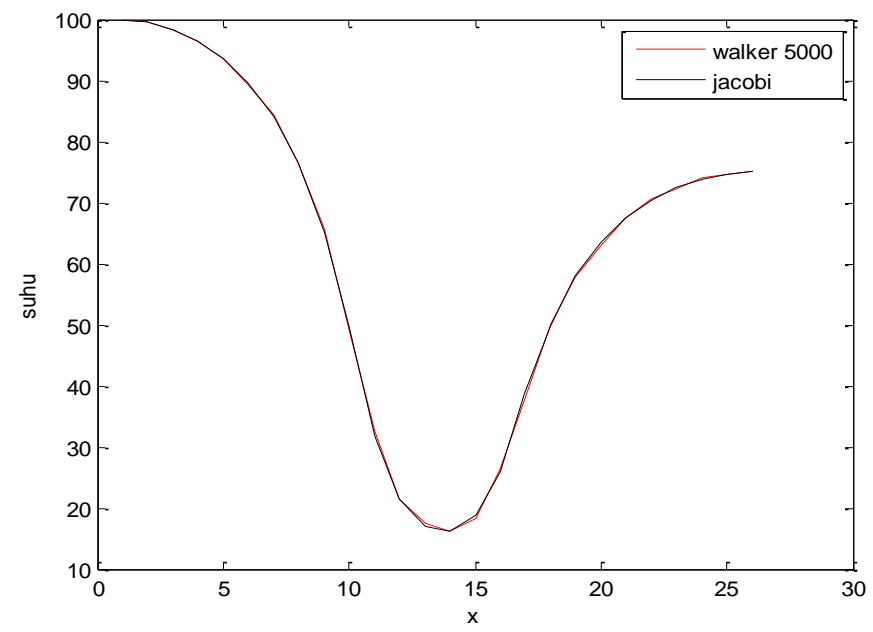

Gambar 8. Grafik Penampang Melintang Plat Geometri Tak Tentu Kondisi (II)

Grafik pada Gambar 8 menggambarkan perpindahan panas dari suhu tinggi ke suhu rendah. Indikatornya adalah titik minimum grafik menunjukkan domain bersuhu rendah. Sedangkan kedua puncak grafik mewakili domain bersuhu tinggi. Perbedaan suhu inilah yang mengakibatkan aliran kalor dapat terjadi.
Hasil plot dan simulasi distribusi suhu pada permukaan geometri tak tentu dengan metode random walk dan jumlah walker hingga 5000 untuk semua kondisi secara umum memiliki penurunan selisih relatif rms terhadap metode iterasi jacobi seperti terlihat pada Gambar (8)

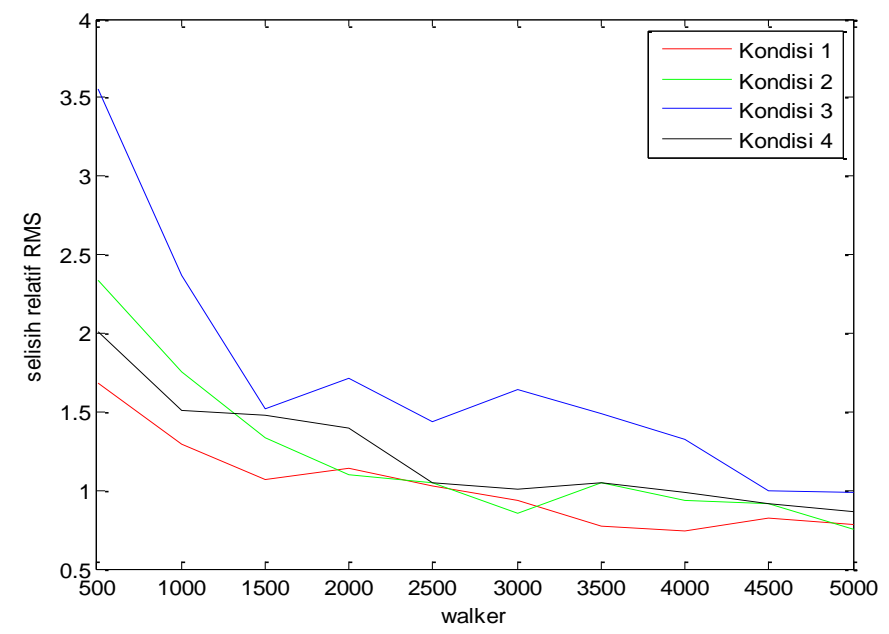

Gambar 9. Grafik Pengaruh Penambahan Walker terhadap Selisih Relatif Rms 2 Kondisi

Grafik Pengaruh Penambahan Walker terhadap Selisih Relatif Rms menunjukkan penurunan selisih relatif RMS. Penurunan secara signifikan terjadi dengan jumlah walker 500-1500 untuk semua kondisi. Lewat dari jumlah itu selisih relatif rms mengalami penurunan dan kenaikan yang tidak fluktuatif. Namun nilai yang dihasilkan cenderung mengecil dan mencapai konvergen dengan walker di atas 5000. Keterbatasan perangkat lunak membuat walker yang disimulasi tidak lebih dari 5000.

Seperti pada kondisi I fungsi green G menyatakan banyaknya frekuensi walker yang berhenti pada syarat batas. Secara geometri walker akan cenderung berhenti pada syarat batas domain terdekat dari sumber panas. Pola ini sama dengan pada kondisi 1. Hal ini disebabkan peluang walker singgah pada syarat batas terjauh tidak lebih besar dari sebaliknya. 


\section{Kesimpulan}

Dari penelitian ini untuk kasus distribusi suhu dalam keadaan tunak pada plat bergeometri tak tentu dapat disimpulkan bahwa solusi Metode Iterasi Jacobi dapat menghampiri solusi analitik dengan baik. Selisih relatif kedua metode sebesar $0,8 \%$. Sehingga Metode iterasi Jacobi dapat dijadikan sebagai validasi untuk Metode Random Walk.

Solusi Metode Random Walk dapat menghampiri solusi numerik metode iterasi Jacobi dengan rentang selisih relatif rms $(0,74-3,55) \%$. Solusi Metode Random Walk mencapai nilai konvergen dengan jumlah walker di atas 5000.

\section{Daftar Pustaka}

[1] Apriansyah. Simulasi Distribusi Temperatur Keadaan Tunak (steady state) Pada Lempeng 2 Dimensi Dengan Menggunakan Metode Cellular Automata Pontianak: Jurusan Fisika FMIPA UNTAN; 2008 (skripsi).

[2] Gapar, Arman Y, Apriansyah. Solusi Persamaan Laplace Menggunakan Metode Random Walk. Positron. 2015; 5(2): p. 65-69.

[3] Sumarji. Simulasi Distribusi Suhu Pada Plat Dua Dimensi Menggunakan Metode Elemen Hingga (Finite Elemen Method) Pontianak: Jurusan Fisika FMIPA UNTAN; 2012 (skripsi).

[4] Gould H, Tobochnik J, Christian W. An Introduction to Computer Simulation Method: Aplication to Physical Systems. 3rd ed. Inc PE, editor. San Francisco: Addison-Wesley; 2007.

[5] Kasman. Analisa Zona Pesisir Terdampak Berdasarkan Model Dispersi Thermal dari Air Buangan Sistem Air Pendingin Bandung: Institut Pertanian Bogor; 2011. 